\title{
A Morphosyntactic Analysis of Dangme Allusive Names
}

\author{
Regina Oforiwah Caesar \\ University of Education, Winneba, Ghana
}

\begin{abstract}
The paper investigates the morphosyntactic features of Dangme allusive names. Dangme belongs to the Kwa family of languages. It is spoken in two Regions of Ghana. As in other cultures, the people of Dangme consider naming as an important aspect of their culture. Allusive names are names based on ideas and beliefs of parents and family members. It is believed that allusive names also have elements of insinuation, and can reflect the mind and emotions of the namer (s) and also have an effect (positive or negative) on the named. This paper discussed one hundred and twenty (120) allusive
\end{abstract}

\footnotetext{
Regina Oforiwah Caesar

Senior Lecturer, Department of Ga-Dangme Education, College of Languages Education, University of Education, Winneba, Ghana

Email: reginacaesar13@gmail.com
}

Received 6 July, 2019; Revised 11 August, 2019; Accepted 16 September, 2019

Copyright (C) 2019 Language Research Institute, Sejong University Journal of Universal Language is an Open Access Journal. All articles are distributed online under the terms of the Creative Commons Attribution Non-Commercial License (http://creativecommons.org/licenses/by-nc/3.0) which permits unrestricted non-commercial use, distribution, and reproduction in any medium, provided the original work is properly cited. 
names in Dangme. Data were collected from both primary and secondary sources. The primary data were collected from twenty one native speakers of Dangme through unstructured interviews. Data were analyzed using categorization and coding. It is to be noted that the morphological analysis revealed that Dangme allusive names have the form of single words, di-morphemic, phrase and clauses reduced to personal names. Syntactically, these sentential names can be simple, embedded or compound sentences which can function as declarative, interrogative and imperative sentences.

Keywords: morphology, syntax, Dangme, allusive/insinuation names.

\section{Introduction}

Dangme belongs to the Kwa group of Niger-Congo family of languages. It is spoken in two Regions of Ghana, Eastern and Greater Accra mainly in South-Eastern Ghana. The people inhabit the coastal area of the Greater Accra Region, east of Accra, and part of the Eastern Region of Ghana. Its closest linguistic neighbours are $\mathrm{Ga}$, Akan and Ewe. Dangme has seven dialects: Ada, Nugo, Gbugblaa, Prampram, Osudoku, Se/Shai, and Krobo (Yilo and Manya).

There are several small communities east of the Volta Region that trace their origins to Dangmeland; most of these have shifted to Ewe as the language of daily life, but others have not (Dakubu 1987, Sprigge 1969 cited in Ameka \& Dakubu 2008: 215). Patches of speakers are also found in Afegame Wenguam in the Volta Region of Ghana and also at Nyetoe and Gatsi in Togoland.

Naming is one of the cultural practices in societies. They are usually given to children at birth. According to Adjah (2011: 3) 'most Ghanaian communities keep the new born baby away from the public view for seven days and brought out on the eight day for the ceremony'. He explains that it is believed the baby is attached to the spirit world 
for the first seven days. The child's humanness and identity is confirmed with the symbolism of a name (Ansu-Kyeremeh 2000: 24). de Klerk (2002) cited in Kongo \& Mends (2016) asserts that personal naming is mainly a linguistic act, intimately linked with hopes, fears, values, thanksgiving and events in people's lives. Mphande (2006), opines that in many African cultures, a name describes the individual that it signifies, the language from which it is drawn and the society that ascribes it. He explains further that a name may indicate the linguistic structures and phonological processes found in the language, the position of the name bearer in the society and the collective history and the life experiences of the people surrounding the individual. Mphande's claim ties in with Baitan (2010: 12) claim that, 'In some African societies, a name is perceived as an important indication of the bearer's behaviour and as a pointer to the name bearer's past, present and future accomplishment'. As Baitan (2010: 10) puts it, 'A name tells a lot about the individual that it signifies the language from which it is drawn and the society that assigns it. de Klerk (2002), Mphande (2006) and Baitan (2010: 10) definitions link up largely with the content of allusive personal names in Dangme which reflect the Dangme people's ideas and beliefs. These names are given based on circumstances surrounding the conception and birth of the referent. According to Egblewogbe (1977), such names are given to children to reflect their parents' or families ideas and beliefs.

The study of personal names falls under onomastic, which includes their form and use Algeo (1992: 727). There are various types of personal names among various cultures. Among these are family names, day names, order of birth names, twin names, circumstantial names, appellations, names based on ideas and beliefs (allusive names).

There have been a number of studies done on personal names in languages of the world; Egblewogble (1977) asserts that personal names are intimately associated with various events in the life of an 
individual, the family and society at large. Odoitei (1989) argues that personal names support human interaction as a medium for communication. (See also Dakubu 2000 and Ansu-Kyeremeh 2000). According to Agbedor (1991), naming among the Ewe people is based on home context principles and philosophical principles. The home context principles are what he describes as the principles that refer to circumstances surrounding the birth of a person. The philosophical principle is what he terms the philosophical thoughts, the belief systems and the general worldview of the Ewe people that reflects their personal lives. Obeng (1998) did a structural linguistic analysis of Akan death prevention names and presented a socio and an ethnolinguistic account of Akan death prevention names and their functions within the Akan communication. He concluded that Akan death prevention names have meanings and they refer to the lives of both the bearers and the name givers. His structural analysis has immersed assistance to the present study on the morphoyntactic analysis of allusive names in Dangme. Agyekum (2006) worked on the sociolinguistic of Akan personal names. Adomako's (2017) study on Akan personal female names indicates that the male names are usually suffixed with the suffixes; $\{-\mathrm{a}\}$ or $\{-\mathrm{aa}\}$ or $\{-\mathrm{wa}\}$. The male names serve as the root names to which the aforementioned suffixes are attached to form the female names in Akan.

Nsoh \& Atintono (2010) studied names and their implications in Farifari culture with particular reference to Gurene and Nankani dialects. They worked on Sigire 'guardian spirit' names and yubo'ote $a$ 'given names'. Dakubu (2000) discussed personal names of the Dagomba. The paper provided an overview of the kinds of names the Dagomba give to their children. She classified names derived from Arabic as 'primary' and names with a religious context as 'traditional'. Appellations and names of Dagomba chiefs were also discussed. Dominic (2014: 58) opines that the majority of Dagaare personal 
names is proverbial in nature and refers to the philosophy of life and the religious attitude of parents. He indicated that such names reflect love, kindness, peaceful co-existence, enmity, jealousy, hatred, hypocrisy, anger, fighting and witchcraft. Dominic's view affirms what J. William Fulbright said in a brainy quote, 'When public men indulge themselves in abuse, when they deny others of fair trial, when they resort to innuendo and insinuation, to libel scandal and suspicion, then our democratic society is outraged, and democracy is baffled' (https://www.brainyquote.com/quotes/j_william_fulbright_330173). The latter explanation is a base for the current study on allusive personal names in Dangme. Unlike Akan, Ewe, Ga, Igbo and the many other languages, the morphosyntactic principles underpinning the formation of personal names especially allusive names of the Dangme people have not been studied.

Although there have been a number of studies done on personal names in various languages, there is scanty literature on personal names used among the people of Dangme. Dangme personal names have been studied by some scholars mostly from cultural perspective. Among the few identified literature on personal names in Dangme include Tetteh (1989) which examined day born names, reincarnation names and also listed some twin names in chapter 8 of the book. Caesar (2015) worked on some naming systems in Dangme and listed some examples of name which were not analysed linguistically. Huber (1993) examined Dangme names under kinship, marriage, initiation and separation rites. In his discussions, he came up with a name as an example as and when it was appropriate but did not do any linguistics analysis of the names. Nyumuah (1998) discussed order of birth names in Dangme. Agbloe (2013) did a sociolinguistic study of some Ga and Dangme personal names and Okai (2017) worked on insinuation names in Manya Krobo. However, the morphosyntactic description of personal names of the Dangme people, have not been examined. The 
purpose of the current study is to fill in the gab in the literature. According to Ephratt (1986), personal names are clearly governed by grammatical rules. The paper hypothesizes that similar grammatical rules can apply to allusive personal names in Dangme.

Dangme has the SVO canonical structure of a clause. It is not uncommon to have personal names that represent clauses in Dangme. According to Onukawa (1995, 1999), Igbo personal names are derived from clauses. He explained that desententialisation is a morphological process where the subject the verb and the complement are fused resulting in the formation of a noun. This assertion is true for the morphosyntactic analysis of allusive personal names in Dangme. Names of any type have morphosyntactic properties; morphemes, phrases, clauses or sentences that function in declarative, imperative, subjection and interrogative structures. This paper discusses the form and structure of allusive personal names in Dangme.

\subsection{The Aim of the Paper}

The aim of this paper is to examine the morphosyntactic analysis of allusive names of Dangme. The paper categorizes and identifies the form and structure of these personal names in Dangme. It further discusses the functions of the structures identified in clauses reduced to personal names in Dangme.

\subsection{Research Questions}

1. What are the forms of Dangme allusive personal names?

2. Which categories of sentence types can be identified in Dangme allusive names?

3. What are the syntactic functions of the clausal allusive names of Dangme? 


\subsection{Significance of the Study}

The findings of the study will add to the relatively limited literature on Dangme naming system and also serve as a basis for further research into other areas of the morphology and syntax of Dangme. It is also hoped that the findings of this study will add to the literature on the morphosyntactic analysis of personal names universal.

\subsection{Methodology and Research Design}

Data were drawn from native speaker's competence and from community consultants from twenty speakers of Dangme, three from each dialectal area; seven teachers of Dangme, seven students studying Dangme at the University of Education, Winneba and seven parent consultants aged between 25 and 70 years. The data were collected through unstructured interviews in September, 2018. The data collected were confirmed with other native speakers of Dangme.

The descriptive approach was used for the analysis of data. The descriptive method according to Mitchell \& Jolly (2012) is a research design that progresses from describing a single variable to describing relationships among variables. They explain that the use of this design involves determining how variables co-vary or how variables relate to another.

\subsection{Organization of the Paper}

Beyond the introduction, the paper is organized into four sections. The second section discusses the concept of allusive names of Dangme morphologically in the following categories; mono-morphemic, dimorphemic and poly-morphemic. It further discusses the types of sentences identified in the clausal names and the functions of the 
60 A Morphosyntactic Analysis of Dangme Allusive Names

clausal names in Dangme. The last section concludes with the findings of the study.

\section{Allusive Names}

An allusive personal name is a name that refers to someone in an indirect way due to circumstance from an external context. It is left to the reader or hearer of the name to make the connection as far as the implied or the inferred meaning of the name is concerned. See also https://educalingo.com/en/dic-en/allusive. According to Adjah (2011), some allusive names could be given to children with the hope of them living up to the virtues or characteristics expressed by the said names. Examples of such names in Dangme include Odehe 'a prominent person', Sikatse 'a rich person', Siadeyo 'a person with good fortune'. He explained further that some of the allusive names are given to children to taunt neighbours, family members or friends. For instance,

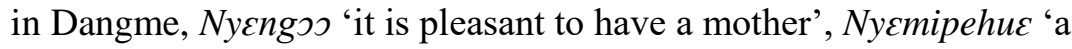
blood relative is worth more than a friend', Adime 'ignore their ways', Wahebens 'we lest expected it', Susmipi 'not enough love', Ojemuno 'you are unique', Adeta 'there is nothing more to be said', Ansngo 'they are not to be blamed', Emaabeke 'it will surely come to pass', Zogbeme 'they are ashamed of themselves', Wanıd osme 'they hate us'.

Adjah (2011: 14) argues that names of an allusive nature are channels for casting insinuations directed at individuals. Most of the times the individual or group may identify him/her or themselves in the names given but cannot re-act to them because no name has been mentioned. Sometimes, parents use the names of their children to recount circumstances surrounding their birth (pleasant, pain, threat, hurt, jealousy, envy, etc.). Such names are given as a way of dealing indirectly with people by either alluding to past events, hurt or threat. 
They are also used as a way of shaming acclaimed enemies (Gilbert 2010). Gilbert (2010) assertion, affirms Adjah's (2011) claim that names may be referred to as "silent dialogues" between the bearer and the hearer and a telegraphic texts about life in general of the bearer.

Some of the allusive names express parents and families beliefs about the existence of God and his works. Names such as Mawukle 'God is great', Mawunge 'God is alive', Mawumunyu 'The word of God' Mawuhwowwemahe 'God does not slumber or sleeps', Mawusus 'God likes it' and Mawuhi 'God is good', Mawubi 'a child of God'. Names of this kind that express ones believe in God are what Agyekum (2006) refers to as theophoric names.

\subsection{Morphological Analysis of Allusive Names in Dangme}

The morphological analysis deals with the form of words. The forms of allusive personal names identified in Dangme include monomorphemic, di-morphomic and poly-morphemic as in Ewe, Akan and other languages. The mono-morphemic allusive personal names are root words that cannot be broken down further to give meaningful components. The mono-morphemic allusive names are mostly metaphors. For instance, Koli, 'an expensive and valuable bead' is used metaphorically to represent a valuable person and Məmっ, 'a flower' is used metaphorically to indicate the beauty of the named or the bearer of the name. This category of allusive names are either used as complements which connotes values for the named or to tease people around the name givers due to circumstances surrounding the birth of a particular child. These forms can however, not be further broken down to give any meaning (lexical or grammatical). Consider the examples in $(1,2)$ : 
62 A Morphosyntactic Analysis of Dangme Allusive Names

(1) a. * M

b. $\left.{ }^{*} \mathrm{~K}\right\lrcorner+1 \mathrm{i}$

(2) a. Odehe 'A great one'

b. Jucni 'Jewellery'

c. Sika 'Money'

d. Dumasi 'Dumas - 'A quality type of cloth'

We observe from examples $(1 \mathrm{a}, \mathrm{b})$ that the meanings of the names are distorted with the split of the root forms (Mo-mo) and (Ko-li). Examples (2a-d) are mono-morphemic. These root words do sometimes not express the complete thought of the name giver unless they are situated in contexts. For instance, Moms, 'flower' implies 'you are the most beautiful thing that has ever happened to me in life'; $K$ sli, 'you are the most valuable thing that I have ever had in life'; Jucni, 'you are worth more than any other thing to me'; Sika 'you are worth more than money to me.'

The Dangme allusive personal names with the di-morphemic structure are the types of name whereby the names can be broken down into two meaningful morphemes unlike in the mono- morphemic names. The two morphemes may be joined as a result of compounding or through affixation as exemplified in (3-5).

(3)

$\begin{array}{lll}\text { a. } & \text { Sika } & \text { yo } \\ \text { NP } & \text { NP } & \\ \text { money } & \text { woman } & \end{array}$

'A rich woman' 
$\begin{array}{ll}\text { b. Manye } & + \text { yo } \\ \text { NP } & \text { NP } \\ \text { luck } & \text { woman }\end{array}$

'A lucky woman'

c. Siade + yo $\rightarrow$ Siadeyo

NP NP

fortune woman

'A woman of fortune'

The noun-noun compound as illustrated in $(3 a-c)$ is a merger of two nouns to form a single noun. That is an animate and inanimate nouns are combined to form a personal name. The animate NP yo 'woman' is a human noun that functions as the head of the compounds in ( $3 \mathrm{a}-$ c), and the inanimate nouns: sika 'money', manye 'luck' and siade 'fortune' modify the head of the compound, yo. It is to be noted that the personal names as in $(3 \mathrm{a}-\mathrm{c})$ are associated with females. These kinds of nouns in Dangme, as in other languages, function as prototypical Dangme nouns, and may function in a clause as a subject and an object (direct and indirect), a complement of a verb, an object of a postposition and also as noun appositives among others in Dangme.

a. Sika + tsu $\rightarrow$ Sikatsu

NP ADJ

money red

'Gold'

b. Mawu + kle $\rightarrow$ Mawukle NP ADJ

God big

'God is great.' 
64 A Morphosyntactic Analysis of Dangme Allusive Names

$\begin{array}{lll}\text { c. } \mathrm{Mawu}+ & \text { nge } & \rightarrow \text { Mawunge } \\ \mathrm{NP} & \text { ADJ } & \\ \text { God } & \text { alive } & \\ \text { 'God is alive.' } & \\ \text { d. } \text { Mawu }+ & \text { ngos } \rightarrow \text { Mawungos } \\ \mathrm{NP} & \text { ADJ } & \\ \text { God } & \text { sweet } \\ \text { 'God is good.' }\end{array}$

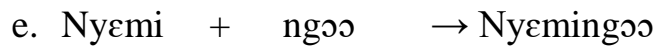

NP ADJ

relative sweet

'It is good to have a relative.'

f. $\mathrm{Bi}+$ ngoo $\rightarrow$ Bingos

NP ADJ

child sweet

'It is beneficial to have a child.'

It is observable in (4a-f) that the allusive names; Sikatsu 'gold', Mawukle 'God is great', Mawunge 'God is alive', Mawungso 'God is good', Nyemingos 'it is nice to have a relative' and Bingso 'it is nice to have a child' are composed of two free morphemes in a compound word. The type of compound identified in (4) is the noun-adjective compound where the noun becomes the head of the compound. The noun-adjective compound dwells on head noun, colour, number, taste, physical property and size. The adjectival component of the compound acts as modifier of the head noun. That is the noun's association with the adjective is that of colour as in (4a), size as in (4b), physical property as in (4c) and taste as in (4d-f). (See also Caesar 2018.) The 
reference to colour in (4a) has another meaning that reads, 'gold'. It is also observed that a syllable of tsùtsù 'red' is elided in the personal name, Sika-tsù.' The referent to nge 'alive', ngəo 'sweet' in (4c-f) expresses the physical property of the head nouns Mawu 'God' nycmi 'a relative' and $b i$ 'a child'. The noun-adjective combination is a left headed compound.

(5) a. Nyakpe + ni $\rightarrow$ Nyakpeni

ADJ NP

wonderful thing

'A wonderful thing' or 'a special person'

b. Afeu + ni $\rightarrow$ Afeuni

ADJ NP

beautiful thing

'A beautiful thing' or 'a beautiful child'

Examples (5a, b) have two free morphemes each that are combined to form adjective-noun compounds. $N i$ 'thing' is the head of the compounds and nyakpe 'wonderful' and afcu 'beautiful' modify the root and head word $n i$. Unlike in the noun-adjective compounds in $(4 a-f)$ which are left headed, the compound words in (5a, b) are right headed compound since the head of the compound is at the right hand side of the construction.

The poly-morphemic allusive names in Dangme are made up of phrases, clauses and sentences. The clauses and sentences function as declarative, imperative and interrogative structures. The morphemic structure of the sentential allusive names in Dangme comprises of free morphemes and some few bound morphemes. The declarative allusive personal names have both the affirmative and the negative forms as exemplified in $(6 a-h)$ and $(7 a-i)$ respectively. 
66 A Morphosyntactic Analysis of Dangme Allusive Names
(6) a. O
hi
pe
ni. $\rightarrow$ Ohipeni
you good
than things
'You are worth more than riches.'

b. E

$$
\text { ngo }
$$

ha $\quad$ me. $\rightarrow$ Engoham $\varepsilon$

3SG

sweet

give them

'Let them be happy.'

c. E

sa

sina.

$\rightarrow$ Esasina

3SG deserves thanks

'He (God) deserves to be praised.'

d. $\mathrm{O}$

$$
\text { je }
$$

yo.

$\rightarrow$ Ojeyo

you

resemble

female

'You resemble a female.'
e. Mawu maa
le wo. $\rightarrow$ Mawumaalewo
God
will feed
US

'God will feed us.'

f. Mawu tsu-0

God work.HAB his

e

ni. $\rightarrow$ Mawutsuseni

'God is at work.'

g. Mawu pee-っ

God do.HAB

ga.

$\rightarrow$ Mawupeeoga

'God is creative.'

h. Ohia la-a

weku.

$\rightarrow$ Ohialaaweku

poverty lose.HAB family

'A pauper is shunned by his family.' 
The morphemic structure of the sentential affirmative declarative allusive names in (6a-e) are made up of free morphemes which are composed of members of the word classes. In ( $6 f-h)$, however, the second roots which are verbs; $t s u$ 'work', pee 'do' and la 'loose' are verbs to which the habitual markers $\{-0\}$ and $\{-\mathrm{a}\}$ are attached. Tsu 'work', pee 'do' and la 'loose' are free morphemes, and $\{-0\}$ in $(6 \mathrm{f}-\mathrm{g})$ and $\{-\mathrm{a}\}$ in $(6 \mathrm{~h})$ are bound morphemes. The bound morphemes; $\{-0\}$ and $\{-\mathrm{a}\}$, inflect for the habitual aspect in the verbs, $t s u$, pee and $l a$.

a. A fic we (e) he $\rightarrow$ Aficweehe they play NEG his body-part 'He/she is held in high esteem.'

b. A de we a no $\rightarrow$ Adewean they say NEG their own 'They do not mind their businesses.'

c. A

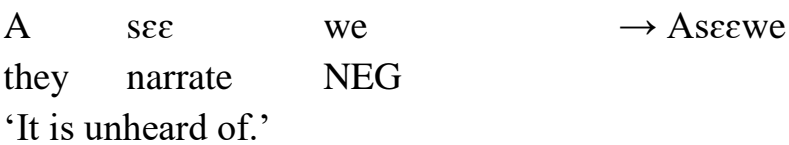

d. Yo da we $\rightarrow$ Yodawe female waste NEG

'A female is not useless.'

e. A

sume wo $\rightarrow$ Asumew 3PL like.NEG 2PL.POSS

'They dislike us.' 
68 A Morphosyntactic Analysis of Dangme Allusive Names

f. E be he kake $\rightarrow$ Ebehekake
it NEG place one
'It is so everywhere.'

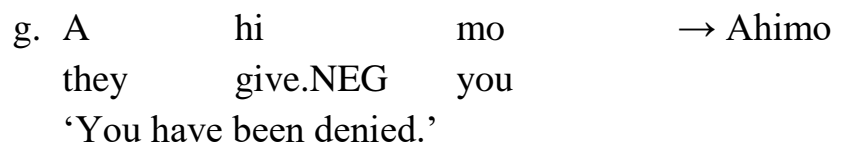

h. Munyu hi tu-mi $\rightarrow$ Munyuhitumi. word can.NEG speak.GER

'Words cannot express it.'

i. No do- $\varepsilon$ yo $\rightarrow$ Nodoryo thing hurt-NEG female

'A female does not get angry.'

The negative declarative sentences in $(7 \mathrm{a}-\mathrm{g})$ consist of free morphemes while (7h) and (7i) are composed of free morphemes and bound morphemes. (7h) has a bound morpheme, the gerund marking suffix $\{-$ mi $\}$ attached to the free form $t u$ 'speak' while in (7i), the negative affix $\{-\varepsilon\}$ is suffixed to the verb root $d s$ 'hurt' to express negation.

\subsection{Syntactic Analysis of Allusive Names in Dangme}

Some proper names (place names and personal names) in Dangme have phrasal and clausal structures because they have specified word class elements incorporated in them. That is, in addition to nouns, the allusive names of Dangme have elements such as verbs, adjectives, adverbs, postposition and conjunctions and can occur in the affirmative or the negative. They usually have the structure of simple and 
compound sentences. As Coastes (2006: 373) put it, 'Names are defined as noun phrases, but these phrases do not necessarily have to be internally structured like noun phrases'. Thus Dangme allusive names are also noun phrases despite the fact that they have elements of the word classes and can inflect for mood (indicative, imperative and interrogative) and polarity.

\subsubsection{Phrasal Allusive Names}

Phrasal allusive names are usually in the domain of noun phrases as exemplified in (8).
(8)
a. A
huno
$\rightarrow$ Ahuno
3PL.POSS NP
'Their husband'
$\begin{array}{lll}\text { b } & \text { Sika } & \text { yo } \\ & \text { NP } & \text { NP } \\ \text { money } & \text { female }\end{array}$
'A rich woman'
c. Ohia
yo
$\rightarrow$ Ohiayo
NP
NP
poverty female
'A poor woman'
d. Buajo
ni
$\rightarrow$ Buajoni
NP
NP
joyful
thing
'A joyful thing or person' 
70 A Morphosyntactic Analysis of Dangme Allusive Names

\begin{tabular}{|c|c|c|}
\hline e. Ja & tsui & $\rightarrow$ Jatsui \\
\hline COMP & $\mathrm{NP}$ & \\
\hline unless & heart & \\
\hline
\end{tabular}

It is observable from example ( $8 \mathrm{a}-\mathrm{d})$ that the allusive names are made up of noun phrases. (8a) is composed of a possessive pronoun $a$ 'their' and the noun head huno 'husband'. Thus, the name Ahuno 'their husband' is a possessive NP. Examples ( $8 \mathrm{~b}-\mathrm{d}$ ) have a combination of two NP. In (8b-c), the first two NPs sika 'money' and ohia 'poverty' are nouns functioning as adjective to qualify the head noun yo 'female'. Sika and ohia are what Dakubu (1987) refers to as descriptive nouns (epithet). However, (8e) has a conditional clause marker, $j a$ 'unless' and an NP tsui 'heart' forming the noun phrase.

\subsubsection{Allusive Names as Simple Sentences}

The Dangme allusive personal names can occur as transitive and intransitive sentences. I discuss the sentential names in this section. I discuss the intransitive structure of names in the following examples in (9).

(9)

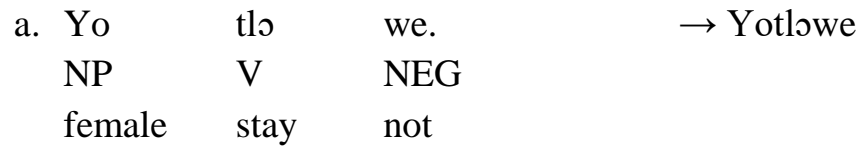

'A woman does not remain unmarried.'

b. Delo

be.

$\rightarrow$ Delobe

AGENTIVE VP.NEG

teller

not there

'There is no one to speak on our behalf.' 

c. Bals be. $\rightarrow$ Balobe
NP VP.NEG
helper not available
'There is no helper.'
d. E maa hi.
$\rightarrow$ Emaahi
3SG FUT VP
it will good
'It shall be well.'

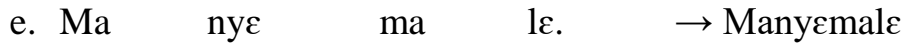 FUT be FUT feed

'I can nurture him/her.'

f. A no hiaa. $\rightarrow$ Anohiaa 3PL.POSS PRO VP their thing important 'They should think about themselves.'

g. Ts $\varepsilon$

he

hiaa. $\quad \rightarrow$ Tschehiaa NP

BODY-PART

VP

'A father is important.'

h. We

mi

nyu.

$\rightarrow$ Weminyu

NP

POSTPO NP

house inside water

'The comforter of the house.'

Sentences (9a-h) have the SV structure with yo, dels, bals, e, a, tse and we functioning as the subjects of the clausal allusive names. 
However, $(9 \mathrm{a}-\mathrm{c})$ are negative constructions. While (9a) has a postverbal particle we 'not' occurring clause finally with the intransitive verb root $t$ lo 'remain' to express negation, $(9 \mathrm{~b}-\mathrm{c})$ have the negative component fused with the intransitive verb root be 'not to have'. In contrast, constructions $(9 d-h)$ are affirmative clausal names. (9d) has the pre-verb future marker maa 'will/shall' occurring in between the subject and the main verb $h i$ 'be good'. (9e) is a serial verb construction with a covert subject. The two verbs accounting for the two events in succession share the same subject which is covert. The pre-verb future marker, $m a$ does not have a scope over the verbs in series. ( $9 \mathrm{f}-\mathrm{h}$ ) have a pronoun, $n s$ 'thing', a body part noun he and a postpositional particle $m i$ 'inside' occurring in between the subjects $a$, tse and we respectively. I discuss the intransitive focused marked form of allusive names in examples (10).

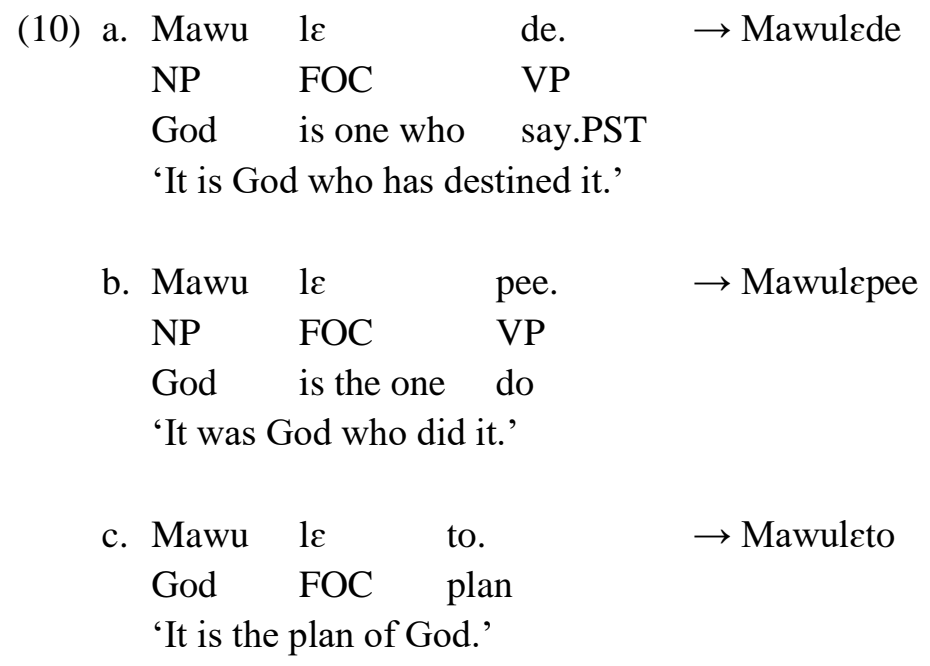

Constructions $(10 \mathrm{a}-\mathrm{c})$ are focused marked intransitive clausal 
names. The constructions have the theophoric name, Mawu 'God' as subjects of the three clauses. The focus marker $l \varepsilon$, which occurred in between the subject of the clause and the intransitive verbs $d e$ 'say', pee 'do' and to 'plan' marks the subject of the clause, Mawu 'God'. The use of the focus marker gives the focused marked element prominence in the construction and also gives emphasis as argued by Halliday (1967) and Dik (1997). Lambrecht (1994: 206b) argues that 'the new information conveyed by focus is that portion of a proposition which cannot be taken for granted at the time of speech. This process of making information new or making a particular constituent stand out does not imply that the focused element is a completely unknown thing which has not been mentioned before, but that the speaker may present it in a special way to call for special attention for that particular element in a clause.' Thus in $(10 \mathrm{a}-\mathrm{c})$, the subject, Mawu 'God' is seen as the only one who is responsible for the action of the verbs: de 'say', pee 'do' and to 'plan'.

I discuss declarative allusive names with the SVO structure in (1114).

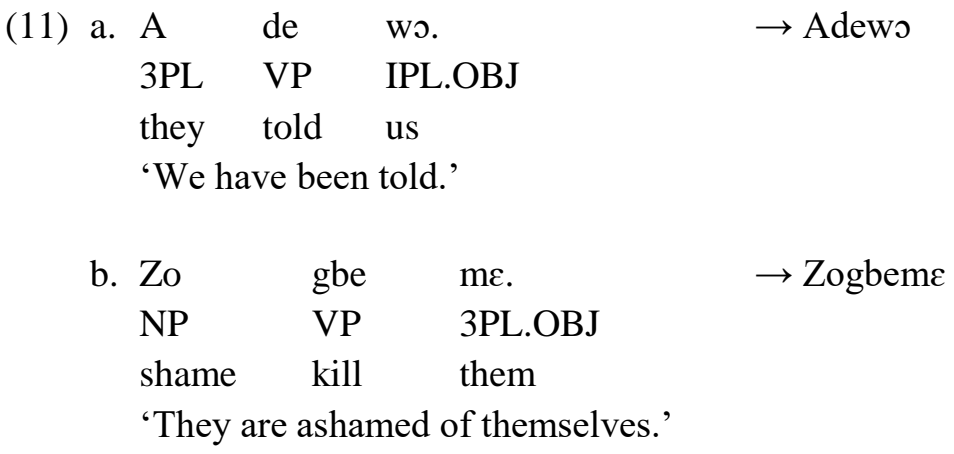


74 A Morphosyntactic Analysis of Dangme Allusive Names

$\begin{array}{llll}\text { c. } \mathrm{O} & \text { je } & \text { me. } & \rightarrow \text { Ojeme } \\ 2 \mathrm{SG} & \mathrm{VP} & \text { 3PL.OBJ } & \\ \text { you resemble them } & & \\ \text { 'You resemble them.' } & & & \\ \text { d. Wa buu } & \text { wa } & \text { he. } & \rightarrow \text { Wabuuwahe } \\ \text { 1PL respect IPL.POSS } & \text { self } & \\ \text { 'We respect ourselves.' } & \end{array}$

e. A nya a nu me. $\rightarrow$ Anyaanum $\varepsilon$ 3PL.POSS BODY-PART PRT VP 3PL.OBJ their mouths the catch them 'Their words should turn against them.'

f. Wa no doว me. $\rightarrow$ Wanodoom $\varepsilon$ 1PL thing pain.HAB 3SG.OBJ 'They are bitter/embittered about our progress.'

Allusive personal names in (11a-f) are simple clauses with the constituents of a clause (subject, verb and object). In constructions, (11a-e), $a$ 'they', $z o$ 'shame', $o$ 'you', wa 'we', $a$ 'their', and $w a$ 'our' are head nouns and de 'say', gbe 'kill', je 'resemble', $n u$ 'catch', dos 'pains/hurt' function as verbs in the constructions while wo 'us' and $m \varepsilon$ 'them are the objects. A nya $a$ 'their mouth' in (11d) and wa no 'our thing/progress' in (11d) are, however, possessive noun phrases.

(12)

$\begin{array}{lllll}\text { a. } & \text { pee } & \text { wo } & \text { gu. } & \rightarrow \text { Apeewogu } \\ \text { 3PL } & \text { VP } & \text { PRO } & \text { ADV } & \\ \text { they } & \text { do } & \text { us } & \text { just } & \end{array}$

'Let them maltreat us.' 
b. A

$\begin{array}{lll}\text { nye } & \text { no } & \text { gu. } \\ \text { VP.NEG } & \text { PRO } & \text { ADV } \\ \text { envy } & \text { human } & \text { just }\end{array}$

'Do not envy baselessly.'

c. A

$\begin{array}{llll}\text { A } & \text { mus } & \text { wo } & \text { gu. } \\ \text { 3PL } & \text { VP } & \text { PRO } & \text { ADJ } \\ \text { they } & \text { laugh } & \text { us } & \text { just }\end{array}$

'Let them laugh at us.'

d. A

$\begin{array}{llll}\text { 3PL } & \text { VP } & \text { PRO } & \text { ADJ } \\ \text { they } & \text { insult } & \text { us } & \text { just }\end{array}$

$\rightarrow$ Anyenogu

3PL VP.NEG PRO ADV

they envy human just

\author{
'Do not envy baselessly.'
}

'Let them insult us.'

(12a-d) considers SVO clausal names with $g u$ 'in vein, just, baseless' occurring clause finally to imply that the actions of the verbs pee 'do/make', nye 'hate', mus 'laugh at', je 'insult' are done without any recourse.

(13)
$\begin{array}{lll}\text { a. Mawu } & \text { ji } & \text { ngua. } \\ \text { NP } & \text { COP } & \text { ADJ }\end{array}$
$\rightarrow$ Mawujingua
God is
big
'God is great.'
b. Mawu ji tse.
God COP father
'God is Lord.'
$\rightarrow$ Mawujitse 
76 A Morphosyntactic Analysis of Dangme Allusive Names

$\begin{array}{lllll}\text { c. Mawu le } & \text { haa } & \text { no. } & \rightarrow \text { Mawulkhaan } \\ \text { NP FOC } & \text { VP } & \text { PRO } & \\ \text { God is the one gives } & \text { human } & \\ \text { 'God is our provider.' } & \end{array}$

The theophoric names in $(13 \mathrm{a}, \mathrm{b})$ are in the form of copular constructions. Mawu 'God' is the head noun for (13a) and (13b) and ngua 'big/great' and tse 'father/Lord' are the complement of Mawu. (13c) is a SVO focus construction. Mawu 'God' is the subject which is being focused marked by $l \varepsilon$. Haa 'gives' is the verb and $n \supset$ 'person', is the object complement of haa 'give'. These theophoric names can be used by both sexes in Dangme.

In addition to the SVO affirmative declarative structure, allusive names also have their negative forms with the SVO structure. I consider personal names with negative connotations in the next set of examples. Names with negative connotations according to Baitan (2010: 55), 'are given to children out of antagonism, dishonest and mistrust among family members or neighbours to serve as psychological therapy to the name giver.' This assertion of Baitan is true for some Dangme allusive personal names. Consider the examples below in (14).

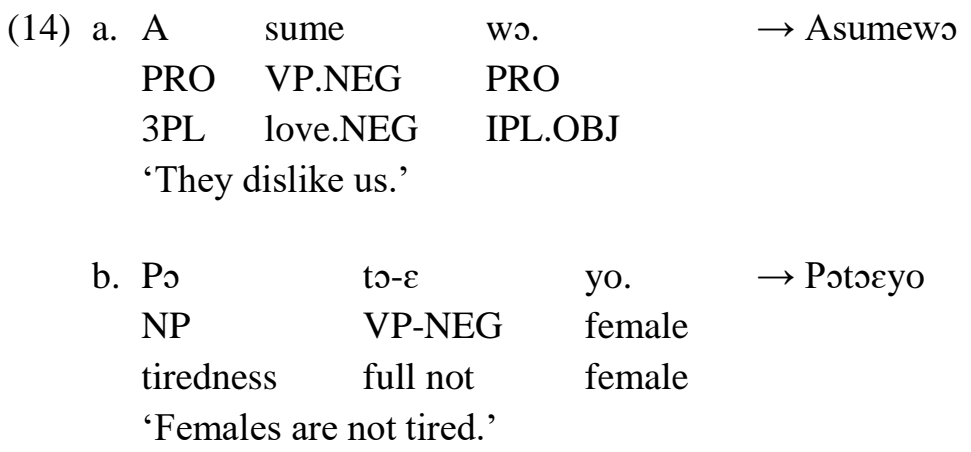


$\begin{array}{llll}\text { c. Wa li } & \text { me. } & \rightarrow \text { Walime } \\ \text { PRO VP.NEG } & \text { 3PL.OBJ } & \\ \text { 1PL know not them } & \\ \text { 'We do not know them.' } & \\ \text { d. } & & & \\ \text { NP } \quad \text { be } & \text { no } & \text { suomi. } & \rightarrow \text { Abenosuomi } \\ \text { they beg not person love } & \\ \text { 'Love is not begged for.' }\end{array}$

Clausal names in $(14 \mathrm{a}-\mathrm{d})$ have the negative verbs sume 'dislike', toe 'be not full', $l i$ 'do not know' and $b \varepsilon$ 'not begged for'. Sume 'do not like' in (14a), $l i$ 'do not know' in (14c) and $b \varepsilon$ 'not begged for' in (14d) are lexical negative verbs. This implies that they have the negative components fused into the root verb. (14b), however, has to 'be full' as the verb root and the negative affix $\{-\varepsilon\}$ is suffixed to it to express negation. That is, the clausal allusive personal name Asumews 'they dislike us' in (14a) is made up of the subject $a$ 'they', a negative verb sume 'dislike' and the object wo 'us'. In (14b), Potวcyo 'females are not tired' has the constituents of a simple clause, $P$ o is an abstract noun functioning as the subject of the clause. toc 'not tired' is the negative verb and yo 'female' is the object complement of toc. Walime in (14c) is composed of a subject $w a$ 'we', a negative verb $l i$ 'do not know' and the direct object $m \varepsilon$ 'them'. The personal name in (14d) is ditransitive. $A$ 'they' is the subject and $b \varepsilon$ 'not begged for' is the verb. $N o$ 'person' is the indirect object and the direct object is suэmi 'love'.

\subsubsection{Allusive Personal Names as Compound Sentences}

Some of the personal allusive names in Dangme have the structure of compound sentences. That is, such names are made up of two 
independent clauses that are joined by a coordinating conjunction $n \varepsilon$ 'and' or se 'but' in Dangme.

(15)

a. $\mathrm{Bi}$ ne a de mo. $\rightarrow$ Bincademo

VP LINK 3PL VP 2SG.OBJ

ask and they tell you

'(You) ask and you would be told.'

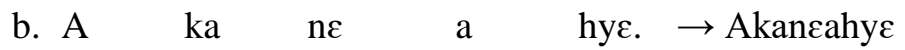

NP VP LINK NP VP

3PL try and 3PL see

'They should try it and see.'

c. A de n $\varepsilon$ e be. $\rightarrow$ Adencebe

NP VP LINK 3SG VP

3PL say and it pass

'Let them say it, it will be over.'

d. De me ne $\quad$ a $\quad$ nu. $\rightarrow$ Demencanu

VP NP LINK 3PL hear

tell 3PL.OBJ and them hear

'Tell them and let them hear it.'

e. A de wo se wa nui. $\rightarrow$ Adewosewanui

NP VP NP LINK NP VP

3PL say 1PL.OBJ but 2PL hear.NEG

'We were told but we did not listen.'

It is observable in each of the names in (15) that they are composed of two independent sentences reduced to personal names. Construction (15a) has the imperative form $b i$ 'ask' as the first clause and a de mo 
'you will be told' as the second clause of the compound construction. The first clause is intransitive and has a covert subject. The second clause, however, is transitive. In $(15 b, c)$, it is realised that all the independent clauses in each compound sentence is intransitive in nature. De $m \varepsilon$ 'tell them' in (15d) and $a$ de wo 'we were told' are transitive clauses. De $m \varepsilon$ in (15d) has a covert subject whilst in (15e) $a$ 'they' is the subject of the first clause, $a n u$ 'they hear'. Wa 'we', is the subject of the second clause of (15e), wa nui 'we did not listen'. A nu 'they hear' and wa nui 'we did not listen' are the intransitive clauses of (15d) and (15e) respectively. The two clauses in (15d) are linked up with the coordinating conjunction $n \varepsilon$ 'and' while in (15e), the clauses are joined with se 'but'. The first clause, a de wo 'we were told', is a transitive construction and the second, wa nui 'we did not listen', is intransitive.

\subsubsection{Imperative Negative Allusive Names}

Dangme has both the affirmative and the negative forms of imperative mood construction. The data have shown that Dangme allusive names are mainly in the imperative negative. The imperative is used to give commands, orders, or express wishes. The imperative is formed by taking the corresponding forms of the indicative construction but without subject pronouns. In Dangme, the imperative negative is the imperative negative morpheme ko or koo 'do not'. The choice of any depends on the tone of the verb it negates. Ko precedes a mono-syllabic verb with a high tone. Also, ko can occur with a disyllabic verb which bears the high tone either in both syllables or in the first syllable of the disyllabic word. In contrast, koo precedes a mono-syllabic verb which bears a low or mid tone, and in a disyllabic verb, it occurs with either verbs in low-low tone, low-mid tone, midmid tone, mid-low tone, low-high and mid-high tone. Ko or koo can 
occur with an overt or covert subject. The imperative negative allusive names request the bearer of the named or its namers not to abide by the action or state of the verb in the sentential name.

(16)

a. Koo hye muone o! $\rightarrow$ Koohyemuones IMP.NEG VP ADV DEF do not look today the 'Do not just consider the present time!'

b. Koo

di me!

$\rightarrow$ Koodime

IMP.NEG VP 3PL.OBJ

'Do not worry about their deeds!'

c. Koo

po a

nya

mi!

$\rightarrow$ Koopoanyami

IMP.NEG VP 3PL.POSS BODY-PART POSTPO do not cut their mouth inside 'Do not mind them!'

d. Koo

hye

$\mathrm{m} \varepsilon ! \quad \rightarrow$ Koohyem $\varepsilon$

IMP.NEG

VP

NP

Do not

look

them

'Do not emulate them!'

e. Koo

nyєe a

se! $\rightarrow$ Koonyecase

IMP.NEG

VP

NP

DV

do not follow their back

'Do not follow their ways!'

It is realised from the data in examples (16a-e) that all the allusive names have covert subjects and have mono-syllabic verbs which are 
negated by the pre-verb imperative negative morpheme, koo. It is observed that all the verbs are in the default low tone. With the exception of (16a) that has an adverbial complement, muэne 0 'today', examples $(16 \mathrm{~b}, \mathrm{c})$ are transitive constructions.

\subsubsection{Interrogative Constructions as Allusive Names}

Certain personal names have the structure of questions in Dangme. In Dangme, in addition to the question particle lo, Dangme uses words and phrases as content question markers (Caesar 2016: 13). According to Boadi (2006: 25), the content words and phrases can stand on their own in a discourse. Two question markers have been identified in Dangme; the nominal type and the adjunct type. The nominal type includes ménj̀ 'who', méní 'what', méní + VP 'what +VP' and méní + $\mathrm{NP}$ 'what + NP'. The adjunct types include jijjé 'where', méní bè 'when', méní hè jè 'why', ényćmé 'how much', kغ̀...kéc̀ 'how' and té....néċ 'which one'. In addition, intonation also plays a role in interrogation in Dangme. The content word question markers can occur at clause initial or clause final position. The question phrases, however, occur as discontinuous phrases $(K \varepsilon \ldots k \varepsilon \varepsilon)$ as in $K \varepsilon$ ma de $k \varepsilon \varepsilon$ ? 'What do I have to say?'

$\begin{array}{llll}\text { a. Jije } & \text { wa } & \text { yaa? } & \rightarrow \text { Jijewayaa } \\ \text { INTW } & \text { 1PL } & \text { VP } & \\ \text { where } & \text { we } & \text { going } & \end{array}$

'Where are we going to or where are we heading towards?'

\begin{tabular}{|c|c|c|c|}
\hline b. Jije & $\mathrm{a}$ & $\mathrm{k} \varepsilon$ & yaa? \\
\hline $\begin{array}{l}\text { INTW } \\
\text { where }\end{array}$ & $\begin{array}{l}3 \mathrm{PL} \\
\text { they }\end{array}$ & take & $\begin{array}{l}\text { VP } \\
g_{0} P R O G\end{array}$ \\
\hline
\end{tabular}


82 A Morphosyntactic Analysis of Dangme Allusive Names

$\begin{array}{lllll}\text { c. Jije a } & \text { guu? } & \rightarrow \text { Jijeaguu } \\ \text { INTW 3PL } & \text { pass.PROG } & \\ \text { 'Where have they been passing?' } & \\ & & & & \\ \text { d. } & \text { Mrni (i) } & \text { ma } & \text { de? } & \rightarrow \text { Mrnimade } \\ \text { INTW I } & \text { AUX } & \text { say } & \\ \text { what } & \text { will } & \text { say } & \\ \text { 'What will/do I say?' } & \end{array}$

$\begin{array}{llll}\text { e. Meno } & \text { ma } & \text { sec } & \text { ha? } \rightarrow \text { Menomasecha } \\ \text { INTW } & \text { AUX } & \text { VP } & \text { INF }\end{array}$

whom will tell to

'Whom will/do I narrate this to?'

f. De o maa le? $\rightarrow$ Deomaale PRT 2SG will know

'Will you know?'
g. E
dos
no
lo? $\rightarrow$ Edoonolo
3SG pain.HAB person QP
'Does it hurt?'

The data in (17) have shown that with the exception of example $(17 \mathrm{~g})$ which is a transitive construction, all the constructions in $(17 \mathrm{a}-$ g) are intransitive interrogative constructions. $(17 \mathrm{a}-\mathrm{c})$ has referential adjunct question words jije 'where' occurring at clause initial position. Jije is followed by the subject NP $w a$ 'we' in (17a) and $a$ 'they' in $(17 \mathrm{~b}-\mathrm{c})$. Yaa 'going' is the intransitive verb for $(17 \mathrm{a}, \mathrm{b})$ and $g u u$ 'been passing' for $(17 \mathrm{c}) .(17 \mathrm{~d}-\mathrm{e})$ have the nominal content question marker $m \varepsilon n i$ 'what' and mens 'who'. Unlike in the referential adjunct question marker jije 'where' which preceded the head noun in $(17 \mathrm{a}-\mathrm{c})$ the 
nominal content question words meni 'what' and mens 'who' do not have any NP acting as the head of (17d) and (17e) because the question words represent the NP (subjects) of the clauses. The verb phrases in $(17 \mathrm{~d}, \mathrm{e})$ are made up of auxiliary verbs and main verbs. The auxiliary verb $m a$ ' will/do' marks the future time and the independent verbs are de 'say' and $s \varepsilon \varepsilon$ 'tell'. Although (17f) does not have any content question word or phrase, it expresses interrogation with intonation. $(17 \mathrm{~g})$ as mentioned earlier is a transitive construction with the pronoun 'it' functioning as the subject of the clause, dos 'hurts' as the independent verb and $n \supset$ 'person' as the object of the clause. The lo is the question particle used in $(17 \mathrm{~g})$.

\section{Conclusion}

This paper sought to discuss the morphosyntactic analysis of Dangme allusive personal names. Distributionally, the morphological properties of Dangme allusive names are drawn from morphemes and also by combining roots with other roots, and with affixes. These are arranged in forming phrases, clauses and sentences at the syntactic level. In the area of morphology, the study revealed that Dangme allusive names can take the form of mono-morphemic, di-morphemic and poly-morphemic. The mono-morphemic names are metaphoric in nature and sometimes do not express the complete thought of the name giver unless they are situated in contexts. For instance, Dumasi 'a type of a quality fabric' could be situated in a context as 'you are the best of everything that I have ever owed.' The data demonstrated that the di-morphemic names are joined as a result of compounding in the area of noun-noun, noun-adjective and adjective-noun combinations and affixation. The poly-morphemic names are made up of phrases, clauses and sentences that function as indicative, imperative and interrogative 
structures in syntactic domain. The phrasal and sentential names have both free and bound morphemes. The bound morphemes were identified as negative and aspectual markers.

Syntactically, the data revealed that allusive names in Dangme can take lexical, phrasal and sentential forms and function as declarative, imperative, interrogative clauses reduced to personal names. At the phrasal level, it was realized that noun phrases are the only forms that the allusive names take in Dangme. At the sentential level, simple and compound clauses were identified. The simple sentences have both the transitive and the intransitive structures as exemplified in (8-10) and (11-14) respectively. The data have shown that a compound sentence is either made up of an imperative clause with a covert subject and a transitive clause or two intransitive clauses or a transitive and an intransitive clause joined with a coordinating conjunction $n \varepsilon$ 'and' or se 'but'.

The data have also shown that allusive names of Dangme occur in the imperative negative form and not in the affirmative. The negative imperative constructions have covert subjects and the imperative negative morpheme ko or koo 'do not' is employed. The choice between them depends on the tone of the verb it negates. Ko precedes a mono-syllabic verb with a high tone and a disyllabic verb which bears the high tone either in both syllables or in the first syllable of the verb. In contrast, koo precedes a mono-syllabic verb with a low or mid tone, and in a disyllabic verb, it occurs either with verbs in lowlow tone, low-mid tone, mid-mid tone, mid-low tone, low-high and mid-high tones. It was realized from the data available that none of the imperative negative forms of the allusive names in Dangme selected the ko imperative marker. The imperative negative allusive names request the bearer of the named or its namers not to abide by the action or state designated by the verb in the sentential name.

With regard to allusive names with interrogative structures, it was 
realized that the nominal and adjunct question words and the $l o$ particle were visible in the data available for this study. Although there are four nominal question word forms in Dangme, two were identified in the interrogative allusive names (ménj̀ 'who', méní 'what'). Also out of the six adjunct question words in Dangme, only jijé 'where' was identified with the allusive names analysed. Although the content word question markers can occur at clause initial or clause final position in Dangme interrogative structures, it was identified that the interrogative words (nominal and adjunct) occurred only at clause initial position in the allusive names.

The data confirms that allusive names of Dangme have linguistic values and phonological processes found in a language as expressed by Algeo (1992), de Klerk (2002), Mphande (2006) and Baitan (2010). Allusive names as personal names identify a person for legal, administrative and other purpose.

In conclusion, the Dangme allusive names, as in languages such as Akan, Ewe, Ga, Igbo and the many others, have morphosyntactic principles underpinning their formation among the Dangme people. The findings of the paper will add up to the limited literature on the language and to the morphosyntactic study of personal names universally.

\section{Abbreviations Used}

$\begin{array}{ll}\text { ADJ } & \text { Adjective } \\ \text { AGENT } & \text { Agentive } \\ \text { ADV } & \text { Adverb } \\ \text { AUX } & \text { Auxiliary Verb } \\ \text { COP } & \text { Copula } \\ \text { COMP } & \text { Complement }\end{array}$




$\begin{array}{ll}\text { DEF } & \text { Definite Article } \\ \text { DEM } & \text { Demonstratives } \\ \text { FOC } & \text { Focus Marker } \\ \text { FUT } & \text { Future } \\ \text { HAB } & \text { Habitual Aspect } \\ \text { IMP } & \text { Imperative } \\ \text { IMP.NEG } & \text { Imperative Negative } \\ \text { INT } & \text { Interrogative Particle } \\ \text { INTW } & \text { Interrogative Word } \\ \text { LINK } & \text { Linker } \\ \text { NEG } & \text { Negative } \\ \text { NP } & \text { Noun Phrase } \\ \text { POSTPO } & \text { Postposition } \\ \text { PRT } & \text { Particle } \\ \text { PL } & \text { Plural Marker } \\ \text { PERF } & \text { Perfective } \\ \text { POSS } & \text { Possessive } \\ \text { PST/PAST } & \text { Past Tense } \\ \text { PROG } & \text { Progressive } \\ \text { QP } & \text { Question Particle } \\ \text { SG } & \text { Singular Marker } \\ \text { SVO } & \text { Subject, Verb, Object } \\ \text { V } & \text { Verb } \\ \text { VP } & \text { Verb Phrase } \\ \text { 2SG } & \text { Second Person Singular Pronoun } \\ \text { 2SG.OBJ } & \text { Second Person Singular Object Pronoun } \\ \text { 3SG } & \text { Third Person Singular Pronoun } \\ \text { 3SG.OBJ } & \text { Third Person Singular Object Pronoun } \\ \text { 1PL } & \text { First Person Plural Pronoun } \\ \text { 1PL.OBJ } & \text { First Person Plural Object Pronoun } \\ \text { 1PL.POSS } & \text { First Person Plural Possessive Pronoun } \\ & \end{array}$


2PL

2PL.POSS

3PL

3PL.OBJ 3SG.POSS
Second Person Plural Pronoun

Second Person Plural Possessive Pronoun

Third Person Plural Pronoun

Third Person Plural Object Pronoun

Third Person Singular Possessive Pronoun 
88 A Morphosyntactic Analysis of Dangme Allusive Names

\section{References}

Adjah, O. 2011. What Is in a Name? Ghanaian Personal Names as Information Sources. African Research and Documentation 117, 3-17.

Adomako, K. 2017. Morphophonological Analysis of Akan Female Family-name Formation. Ghana Journal of Linguistics 6.3, 1-32. Agbedor, P. 1991. What Is in a Name? Working Papers of Linguistic Circle of the University of Victoria 10.1, 39-48.

Agbloe, C. 2013. A Sociolinguistic Analysis of Ga-Dangme Personal

Names. Unpublished M.Phil. Thesis, University of Education, Winneba.

Agyekum, K. 2006. The Sociolinguistic of Akan Personal Names. Nordic Journal of African Studies 15.2, 206-235.

Algeo, J. 1992. Onomastics. In T. McArthur (ed.), The Oxford Companion to the English Language 727-729. Oxford: OUP.

Ameka, F. \& M. Dakubu. 2008. Aspect and Modality in Kwa Languages. Amsterdan: John Benjamins.

Ansu-Kyeremeh, K. 2000. Communicating Nominatim: Some Social Aspects of Bono Personal Names. Research Review 16.2, 19-33.

Baitan, B. 2010. A Morphosemantic Analysis of Ruhaya Personal Names. M.A. Thesis, University of Dar es Salaam.

BrainyQuote. 2019. When Public Men Indulge Themselves in Abuse, When They Deny Others a Fair Trial, When They Resort to Innuendo and Insinuation, to Libel, Scandal, and Suspicion, Then Our Democratic Society Is Outraged, and Democracy Is Baffled. Available at $<$ https://www.brainyquote.com/quotes/j_william_ful bright_330173>.

Boadi, L. A. 2006. Three Major Syntactic Structures in Akan. Accra. Black Mask Limited. 2010. Akan Noun Phrase, Its Structure and 
Meaning. Accra: Black Mash Limited.

Caesar, R. 2016. An Analysis of Interrogative Constructions in Dangme. Journal of Literature, Languages and Linguistics 21, 35-49.

Caesar, R. 2018. Compounding in Dangme. African Journal of Interdisciplinary Studies 11.1, 52-73.

Caesar, T. 2015. E pees mo Dangme no. Accra: Moonlight Press.

Coastes, R. 2006. Properhood. Language 82.2, 356-382.

Dakubu, M. 1987. The Dangme Language: An Introductory Survey. London: Unimax.

Dakubu, M. 2000. Personal Names of the Dagomba. Research Review 16.2, 53-66.

Dik, S. 1997. The Theory of Functional Grammar I: The Structure of the Clause. Berlin: Mouton de Gruyter.

Dominic, C. 2014. The Socio-Cultural Study of Dagaare Personal Names. Unpublished M.Phil. Thesis, University of Education, Winneba.

Educalingo. 2019. What Does Allusive Mean in English? Available at $<$ https://educalingo.com/en/dic-en/allusive $>$.

Egblewogbe, E. 1977. Ewe Personal Names: A Sociolinguistic Study. Unpublished M.A. Thesis, University of Ghana.

Ephratt, M. 1986. Is There a Grammar to Settlement Names? Lesonenu 50, 137-150.

Gilbert, M. 2010. Disguising the Pain of Remembering in Akwapim. Journal of International African Institute 80.3, 426-452.

Halliday, M. 1967. Notes on Transitivity and Theme in English Part 2. Journal of Linguistics 3.2, 199-244.

Huber, H. 1993. The Krobo: Traditional Social and Religious Life of a West African People. Friboury: University Press Fribourg.

de Klerk, V. 2002. Changing Names in the "New" South Africa: A Diachronic Survey. Names 50.3, 201-221.

Kongo, E. \& E. Mends. 2016. Language Learning: A Morphosyntactic 
90 A Morphosyntactic Analysis of Dangme Allusive Names

Analysis of Contemporary Ewe Personal Names. Proceedings of INCEDI 2016 Conference 3-17. Methodist University College Ghana.

Lambrecht, K. 1994. Information Structure and Sentence Form. Cambridge: CUP.

Mitchell, M. \& Jolly, J. 2012. Research Design Explained. Eighth Edition. Austrailia: WADSWORTH CENGAGE Learning.

Mphande, L. 2006. Naming and Linguistic Africanism in AfricanAmerican Culture. Selected Proceedings of the 35th Annual Conference on African Linguistics 104-113. Somerville, MA: Cascadilla Press.

Nsoh, E. \& A. Atintono. 2010. Personal Names among Farifari Speakers of Northen Ghana. Journal of African Cultures and Languages 1.1, 77-85.

Nyumuah, J. 1998. Krobo Custom. Denmark: KØge og Omegns.

Obeng, S. 1998. Akan-Death-Prevention-Names: A Pragmatic and Structural Analysis. New York: Ohio University.

Odoitei, I. 1989. What Is in a Name? The Socio and Historical Significance of Ga Names. Research Review 5.2, 34-51.

Okai, F. 2017. Blakpa bichi ke nihi ne a daa si ke ha nge Manya Klo. Unpublished Long Essay, University of Education, Winneba.

Onukawa, M. 1995. A Re-Analysis of the So Called Igbo DeSentential Nominal. In N. Wmenanjo \& O. Ndimele (eds.), Issues in African Languages and Linguistics: Essays in Honour of Kay Williamson 266-278. Aba: National Institute for Nigerian Languages.

Onukawa, M. 1999. The Significance of the Verb 'Kwe' in Igbo Personal Names. Anthropological Linguistics 41.1, 107-119.

Sprigge, R. 1969. Eweland's Adangbe: An Enquiry into an Oral Tradition. Transactions of the Historical Society of Ghana 10, 87-128. Tetteh, E. 1989. Mo dem 'koo! Accra: Bureau of Ghana Languages. 


\section{Appendix}

The table below presents additional data on allusive names of Dangme which are arranged not in any particular order.

\begin{tabular}{|c|c|c|c|c|}
\hline $\mathbf{S} / \mathbf{N}$ & Word Division of Al & Isive Name & Allusive Name & Gloss \\
\hline 1 & $\begin{array}{ll}\text { Mawu } & \text { pee } \\
\text { NP } & \text { VP }\end{array}$ & $\begin{array}{l}\text { no. } \\
\text { NP }\end{array}$ & Mawupeens & God does things. \\
\hline 2 & $\begin{array}{lll}\text { Mawu } & \mathrm{k} \varepsilon & \text { wo } \\
\text { NP } & \text { AUX } & \text { PR }\end{array}$ & $\begin{array}{l}\text { nge. } \\
\text { COP }\end{array}$ & Mawukewonge & God is with us. \\
\hline 3 & $\begin{array}{lll}\text { Mawu } & \text { tsuo } & \text { e } \\
\text { NP } & \text { VP } & 3 S G .\end{array}$ & $\begin{array}{ll} & \text { ni. } \\
\text { OSS } & \text { NP }\end{array}$ & Mawutsuðeni & $\begin{array}{l}\text { God works } \\
\text { according to his } \\
\text { own will. }\end{array}$ \\
\hline 4 & $\begin{array}{l}\text { saa } \\
\text { VP }\end{array}$ & $\begin{array}{l}\text { yo. } \\
\text { NP }\end{array}$ & Gbasaayo & $\begin{array}{l}\text { Marriage befits a } \\
\text { woman. }\end{array}$ \\
\hline 5 & $\begin{array}{l}\text { saa } \\
\text { VP }\end{array}$ & $\begin{array}{l}\text { yo. } \\
\text { NP }\end{array}$ & Besaayo & $\begin{array}{l}\text { Sweeping is one of } \\
\text { the core duties of a } \\
\text { woman of beauty. }\end{array}$ \\
\hline 6 & $\begin{array}{llll}\text { A } & \text { de } & \text { we } & \text { a } \\
\text { PRO } & \text { VP } & \text { NEG } & \text { 3PI }\end{array}$ & $\begin{array}{ll} & \text { n॰. } \\
\text { POSS } & \text { NP }\end{array}$ & Adeweans & $\begin{array}{l}\text { They cover their } \\
\text { ways up, and } \\
\text { gossip about others. }\end{array}$ \\
\hline 7 & $\begin{array}{llll}\text { Wa } & \text { kpe } & \text { we } & t \\
\text { PRO } & \text { VP } & \text { NEG } & \text { I }\end{array}$ & & Wakpewete & $\begin{array}{l}\text { We do not chew } \\
\text { stones. }\end{array}$ \\
\hline 8 & $\begin{array}{lll}\text { E } & \text { ngo } & \text { ha } \\
\text { PRO } & \text { VP } & \text { VP }\end{array}$ & $\begin{array}{l}\mathrm{m} \varepsilon \\
\mathrm{PRO}\end{array}$ & Engohame & $\begin{array}{l}\text { They should be } \\
\text { happy. }\end{array}$ \\
\hline 9 & $\begin{array}{lll}\text { E } & \text { maa } & \text { do } \\
\text { PRO } & \text { FUT } & \text { VP }\end{array}$ & $\begin{array}{l}\mathrm{m} \varepsilon . \\
\text { PRO }\end{array}$ & Emaadøme & They will be hurt. \\
\hline 10 & $\begin{array}{ll}\text { Ekome } & \text { suっ. } \\
\text { ADJ } & \text { VP }\end{array}$ & & Ekomesuo & Some like it. \\
\hline 11 & $\begin{array}{lll}\text { A } & \text { de } & n \varepsilon \\
\text { PRO } & \text { VP } & \text { CONJ }\end{array}$ & $\begin{array}{ll}\text { e } & \text { be. } \\
\text { PRO } & V P\end{array}$ & Adencebe & $\begin{array}{l}\text { Let them say it. It } \\
\text { will not be forever. }\end{array}$ \\
\hline
\end{tabular}


92 A Morphosyntactic Analysis of Dangme Allusive Names

\begin{tabular}{|c|c|c|c|}
\hline 12 & $\begin{array}{llll}\text { Waa } & \text { hi } & \text { mi } & \text { ja. } \\
\text { PRO } & \text { VP } & \text { POSTPO } & \text { ADV }\end{array}$ & Waahimija & $\begin{array}{l}\text { Let us be in it like } \\
\text { that. }\end{array}$ \\
\hline 13 & $\begin{array}{lll}\text { Nyumu } & \text { he } & \text { hia. } \\
\text { NP } & \text { BODY-PART } & \text { VP }\end{array}$ & Nyumuhehia & $\begin{array}{l}\text { A male is } \\
\text { important. }\end{array}$ \\
\hline 14 & $\begin{array}{llll}\text { Wa } & \text { he } & \text { be } & \text { no. } \\
\text { PRO } & \text { NP } & \text { VP } & \text { NP }\end{array}$ & Wahebeno & $\begin{array}{l}\text { We least expected } \\
\text { it. }\end{array}$ \\
\hline 15 & $\begin{array}{lll}\text { Ma } & \text { tsuo } & \text { so- } \varepsilon . \\
\text { NP } & \text { ADJ } & \text { VP.NEG }\end{array}$ & Matsuosoc & $\begin{array}{l}\text { All nations are not } \\
\text { equal. }\end{array}$ \\
\hline 16 & 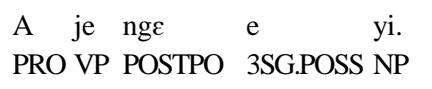 & Ajengeyi & $\begin{array}{l}\text { It happened in their } \\
\text { presence. }\end{array}$ \\
\hline 17 & $\begin{array}{lll}\text { Wa } & \text { le } & \text { me. } \\
\text { PRO } & \text { VP } & \text { PRO }\end{array}$ & Walem $\varepsilon$ & We know them. \\
\hline 18 & $\begin{array}{llll}\text { E } & \text { dos } & \text { no } & \text { lo? } \\
\text { PRO } & \text { VP } & \text { PRO } & \text { QP }\end{array}$ & Edəon๖lo & Does it hurt? \\
\hline 19 & $\begin{array}{lll}\text { Yo } & \text { hu } & \text { no. } \\
\text { NP } & \text { INT } & \text { NP }\end{array}$ & Yohuno & $\begin{array}{l}\text { A female is also a } \\
\text { human. }\end{array}$ \\
\hline 20 & $\begin{array}{lll}\text { O } & \text { pe } & \text { sika. } \\
\text { PRO } & \text { VP } & \text { NP }\end{array}$ & Opesika & $\begin{array}{l}\text { You are worth more } \\
\text { than money (riches). }\end{array}$ \\
\hline 21 & $\begin{array}{llll}\text { A } & \text { he } & \text { be } & \text { no. } \\
\text { PRO } & \text { VP } & \text { NEG } & \text { PRO }\end{array}$ & Ahebeno & $\begin{array}{l}\text { They least expected } \\
\text { it. }\end{array}$ \\
\hline 22 & $\begin{array}{llll}\text { A } & \text { he } & \text { su } & m \varepsilon . \\
\text { PRO } & \text { BODY-PART } & \text { VP } & \text { PRO }\end{array}$ & Ahesume & $\begin{array}{l}\text { They are self- } \\
\text { sufficient. }\end{array}$ \\
\hline 23 & $\begin{array}{lll}\text { Nya } & \text { des } & \text { no. } \\
\text { NP } & \text { VP } & \text { NP }\end{array}$ & Nyadeons & A mouth speaks. \\
\hline 24 & $\begin{array}{lllll}\text { E maa di } & \text { a } & \text { he } \\
\text { PRO FUT VP } & \text { PRO } & \text { BODY-PART }\end{array}$ & Emaadiahe & $\begin{array}{l}\text { It will favour our } \\
\text { hunt them. }\end{array}$ \\
\hline 25 & $\begin{array}{ll}\mathrm{mi} & \text { kle. } \\
\text { POSTPO } & \text { ADJ }\end{array}$ & Jemikle & $\begin{array}{l}\text { The world is a big } \\
\text { place. }\end{array}$ \\
\hline 26 & $\begin{array}{lllll}\text { Ja } & \text { o } & \text { su } & \text { a } & \text { he. } \\
\text { PRT } & \text { PRO } & \text { VP } & \text { PRO } & \text { BODY-PART }\end{array}$ & Jaosuahe & $\begin{array}{l}\text { Unless you get } \\
\text { closer to them. }\end{array}$ \\
\hline 27 & $\begin{array}{l}\mathrm{m} \varepsilon \\
\mathrm{PRO}\end{array}$ & Zogbem $\varepsilon$ & $\begin{array}{l}\text { They are ashamed } \\
\text { of themselves. }\end{array}$ \\
\hline
\end{tabular}




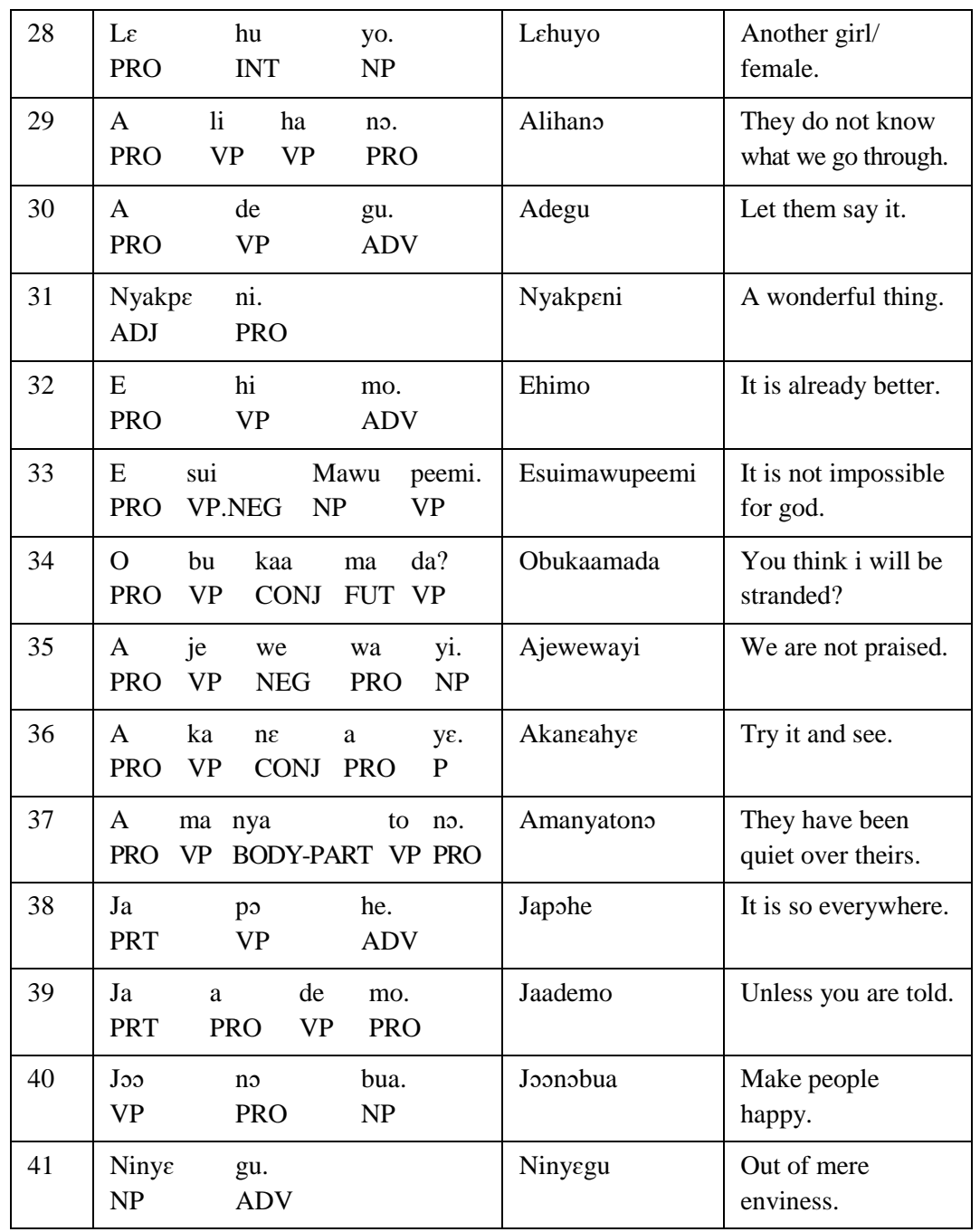

